\title{
39. 万能型人工臓器機能測定装置の開発
}

\section{1. 研究目的}

近年, 人工臓器の進歩は目覚さしく, 循環系 および代謝系人工荍器として，すでに人工血 管, 人工弁, 人工心肺㧍よび人工肺, 人工慜臟 人工肝藏などが臨床に使用され，人工心臟も臨 床応用に近づきつつある。そしてこれらの人工 臓器については，小型化，ディスポーザブル 化，機能の向上など年々その改良が加えられて いる。このため，新たに開発㧍よび改良された 人工臟器の機能評何の方法とそのための装置が 重要となり，各人工臟器について独自の方法や 装置が考案されてきた。しかし，最近のように 一つの施設で各種の人工臟器を取扱うょうにな ると各人工臟器に対して機能評洒の装置が必要 となりそのスペースの問題と検定のための装置 のセットアップのわずらわしさが閣題となって きている，そこで脈管采の全ての人工臟器に適 用可能な機能测定装置が開発で恚れ洪，人工臟 器の開発には極めて有男なものと考沉られる。

\section{2. 対象となる人工藏器と湘定すべき機能} 脈管系の人工臟器の中でも, 人工心臓, 人工 弁, 人工肺, 人工腎臓, 人工肝臓などはその進 歩が激しく，簡便に機能测定の可能な装置の開 発が強く望京れている。表1はこれらの人工 臓器の測定す心゙き主な機能を志とめたものであ る。これによると，人工心臓や人工弁では，流 量特性や抵抗，岕るいは流線の観察や耐久性な どが間題になり，人工湖では，流量特性の他に

\footnotetext{
* 東京大学医学部医用電子研究施設

*2 東京農工大学保健管理センター

*3 国立病院医療センター
}

井街宏*藤正嚴*岩井矩成* 三宅仁*滝户直人*河野明正* 渥美和彦*西坂 剛 ${ }^{* 2}$ 大道 久*3

\section{表 1 対象となる人工臟器と測定すべき機能}

人工心臟：流量特性（拍出量, 流出入圧, 駆動条 件) 流出入抵抗, 耐久性, 流線観察

人工 弁 : 圧損失, 開閉時の動特性 流線観察, 耐久性

人工 肺: $\mathrm{O}_{2}, \mathrm{CO}_{2}$ 交換能 (血流量, $\mathrm{O}_{2}$ 流量, 圧) 圧損失

人工腎臟: 物質透析, 吸着, 沪過能 (血圧, 血流 量, 灌流液条件)

圧損失

人工肝臟：物質吸着能 (血流量)

ガス交換能が，また人工腎臟や人工肝臓では血 液側の圧, 流量条件之物質透析, 吸着, 罳過能 などの関倸が重要な機能と考えられる。

ところが，これらを良く観ると，测定される べき機能は，血液側（生体側）と非血液側（体 外側）の2つに大別でき, 前者では流量, 流出 入珐，压損失などが，後者では駆動条件やガス 交換能，灌流液条件などその人工臓器の制御パ ラメータが関与してくる. 従って, 生体側に見 たてた血液側回路にはほとんどの脈管系人工臓 器に其通した測定機能を含ますことができこ こ のよらな装置ができれば，単にテストすべき人 工臓器を接続し，人工心臟なら駆動装置側，人 工肺なら気柜侧，人工腎なら濩流液侧回路を設 定するだけで簡単に機能の测定が可能となる。

\section{3. 装置の備えるべき条件とその開発}

上述のような機能を有するために本装置の備 えるべき条件としては，

（1）定流量ポンプ：脈管系人工臟器の機能 定量的に把握するためには，その人工臟器 
医器学 Vol. 48, Suppl. (1978)

を流れる流量を任意の值に設定でき，しか も人工藏器の種類により, 拍動流と定常流 のどちらでもが選択可能にする必要があ る.

（2）抵抗要素：テスト部流路の内圧を任意の 值に設定できる必要がある。

(3) コンプライアンスタンク：拍動流の場合 にその脈圧および圧波形を調節するために 必要.

(4)リザーヴァタンク, 循環回路：血液や擬 似血液，生食水など量の限られた任意のテ スト流体を流し得るよう，大気開放のリザ

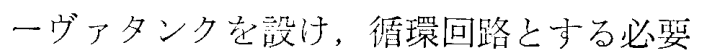
がある。

（5）循環液温の制御：テスト部の洐温娄任意 位留定できるよう，リザー少アタンクにヒ

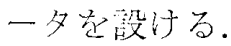

(6) 流入・流出量竍測 $(F)$ ：人工臟器人の流

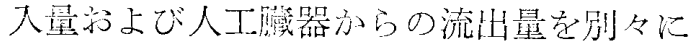
計測可能とする密琵が市る。

(7) 流入・流出压测测 $(\mathrm{P})$

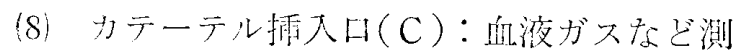
这に力テーテル姿必要と寸るものに効処で

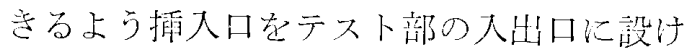
名必望方市。

(9) サンプリングロ

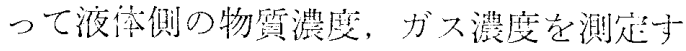
るためにテスト部人期化必望。

以上のような条件を借えた万能㤠人工臟器機

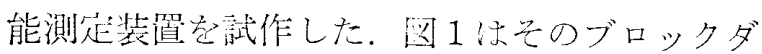
イアグラムであり，军斯1はその外観を元す。 装置は，幅，奥行，高さが各↔ $51 \mathrm{~cm} \times 60 \mathrm{~cm} \times$ $71 \mathrm{~cm}$ の大きさで，点常流ポンプとしてローラ ポンプ，また拍動流ポンプとしては人工心臓用 ポンプが储えられ，切換えが可能となってい る。卡た，抵抗要素としてはダートバルブを用 いこのバルブとリザーヴァタンクの間にはロ タメータ登入れ，コンプライアンスタンク部に は玨力計をつけ，定常的な流星や圧を監視でき るようにしてある。過度的な压や流量およびそ の記録に快電磁流量竍プローブ，電気血压計プ ローブが入出口に装着可施である。また，テス ト部の竍後の管は任意の物性のものがプラグイ

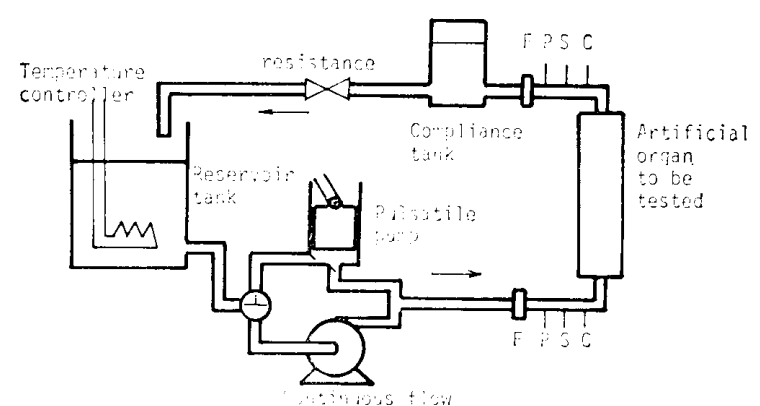

図 1 万能型人工臟器機能測定装置のブロック ダイアグラム

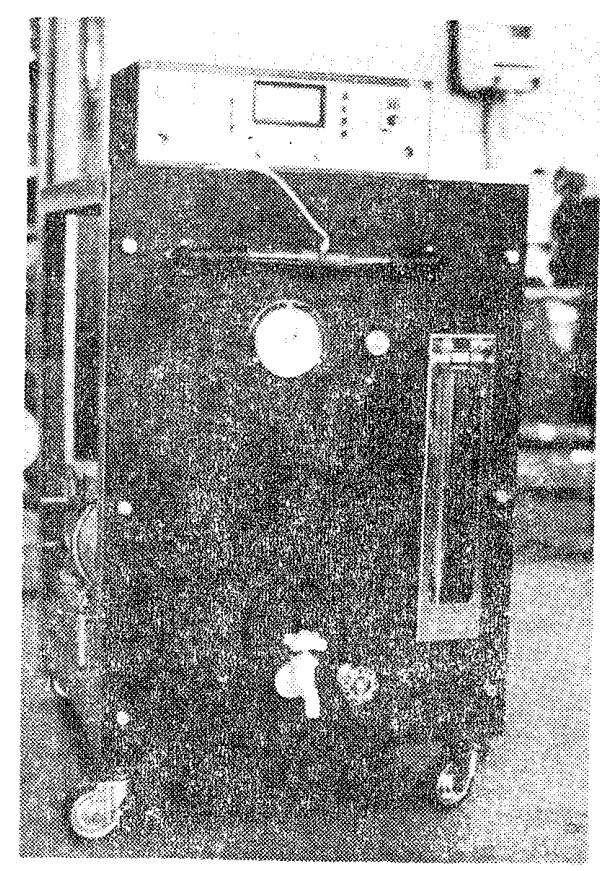

写真 1 試作した万能型人工臟器機能測定装置 の外観

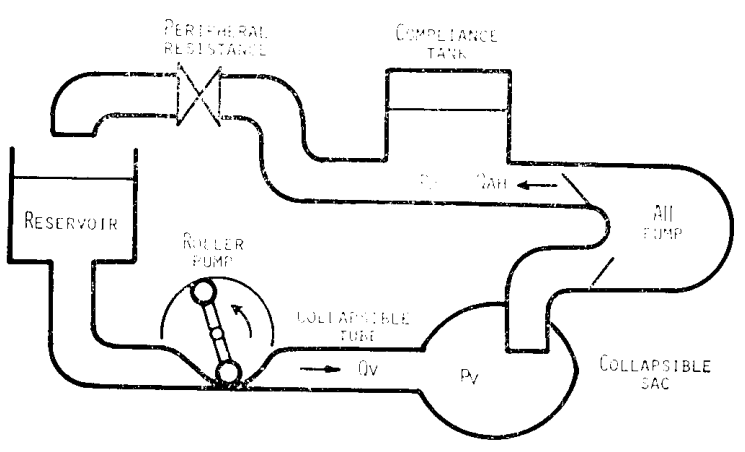

図2 本装置を人工心臓ポンプ僟能テストに用 いた例

ンで告るようなっている。

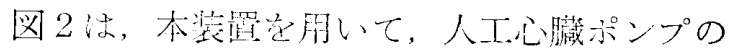
機能テスト离行った例で方る。ここでは人工心

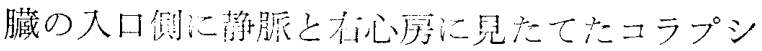




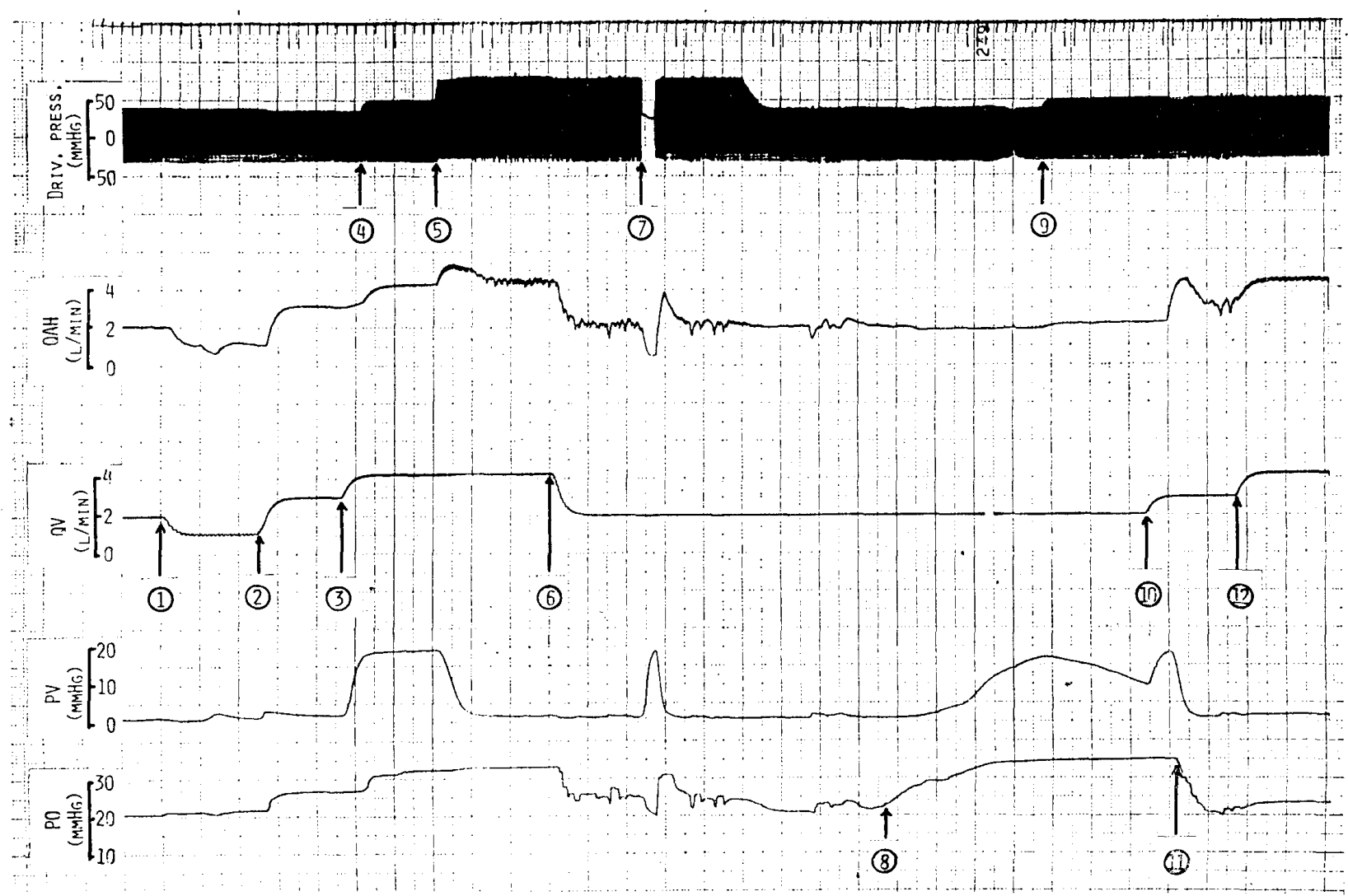

QAH : 人工心臟拈出量

QV : ローラポンプ流量
$\mathrm{PV}:$ : ラプシブルサック内压

$\mathrm{PO}$ ：人工心臟出口圧

\section{図 3 本装置による人工心臓ポンプの特性}

ブルチューブとサックをプラグインしてある。 また図 3 は，これから得られた結果であり，静 脈環流をシミュレートしたローラポンプの変化 に対する人工心藏ポンプの応答を極めて良く示 している.

\section{4. まとめ}

脈管系の全ての人工臟器に適用可能な人工臓 器機能測定装置を試作したが，本装置を用いれ ば，テストすべき人工臟器の血液回路㧍よびそ の計測システムが確保でき, 極めて簡便僟能
の測定ができる。一般にこのような血液回路を つくる場合，とも寸れば生体循環系全体を模擬 したシミュレータをつくりがちであるが，その ようにするとそのシミュレータ自体の特性が人 工臟器の特性にオーバーラップしてきて正しい 機能をつかみ難い，本装置は人工臟器を接続す る付近の流路の特性のみ生体をシミュレート し，この点を解決したもので，今後本装置を発 展させて，標準的な人工藏器の検定方法の開発 に役立たせるつもりである。 